\title{
Anatomical study of the relationship of impacted mandibular third molar root apex to inferior alveolar canal in Kurdistan population using orthopantomogram \\ Received: 5/5/2016 \\ Accepted: $30 / 10 / 2016$
}

\begin{tabular}{rrr}
\hline Fedil Andraws Yalda* & Ali Sultan Al-Refai** & Khoshee Salih Hameed Al-Mufty* \\
\hline Abstract &
\end{tabular}

Background and objective: Extraction of an impacted mandibular third lower molar tooth is one of the common surgical procedures that may lead to the damage of inferior alveolar nerve due to roots proximity to the mandibular canal. This study aimed to know the relative relationship and proximity of the mandibular third molar roots to the inferior alveolar canal in relation to gender, age, depth of impaction, relation with ramus, and type of angulation of the impacted tooth in Kurdistan population.

Methods: A sample of 366 digital panoramic radiographs of patients with impacted mandibular third molar was studied. Panoramic radiographic signs images were evaluated for the presence of root contact with the superior border of the mandibular canal, darkening of the roots apex, deflected roots, narrow root, superimposition of the canal, interruption of the white line, diversion of the inferior alveolar canal, and narrowing of the inferior alveolar canal. The depths of impaction, relation with ramus, and type of angulation were also studied.

Results: Significant relation of the proximity of the mandibular third molar roots to the inferior alveolar canal with the gender $(P=0.001)$ and age $(P<0.001)$ were seen. A significant relation of the proximity of the mandibular third molar roots to the inferior alveolar canal with the depth of impaction $(P<0.001)$, relation with the ramus $(P=0.004)$, and angulation of impaction were also seen $(P<0.001)$.

Conclusion: Significant relation of the proximity of the mandibular third molar roots to the inferior alveolar canal with gender, age, depth of impaction, relation with the ramus, and angulation of impaction were seen.

Keywords: Panoramic radiographs; Inferior alveolar canal; Impacted mandibular third molars.

\section{Introduction}

The inferior alveolar nerve enters the mandibular canal through the mandibular foramen on the medial surface of the ascending mandibular ramus, along with the inferior alveolar artery, the inferior alveolar vein and the inferior alveolar lymphatic vessels and together they are called the inferior alveolar neurovascular bundle. ${ }^{1}$ The mandibular canal containing this neurovascular bundle runs obliquely downward and forward in the ramus, and then horizontally forward in the body till the mental foramen. The neurovascular bundle is generally well protected within the mandibular canal, however, may have areas of perforation and exposure where roots of the mandibular teeth are in contact with the canal in the third molar region. ${ }^{2}$ The relationship of these mandibular third molar roots to the variable position and anatomy of the mandibular canal containing the inferior alveolar nerve may at times present the surgeon with even more difficult surgical challenges, with unpredictable and undesirable surgical outcomes. $^{3-5}$ Different complications like inadvertent crush injury, stretch injury, or even severing of the inferior alveolar nerve may occur when the relationship is not

* Department of Oral Diagnosis, College of Dentistry, Hawler Medical University, Erbil, Iraq.

** Department of Oral and Maxillofacial Surgery, College of Dentistry, Hawler Medical University, Erbil, Iraq. 
clear. $^{6-12}$ The most appropriate radiographic techniques relied on by surgeons for many years have been an orthopantomogram (OPG). The OPG scanners require less technical skill to operate and have cheaper associated running costs than CT machines, with a relatively low radiation dosage. ${ }^{13}$ An overall view of all of the important anatomical structures is possible in a single OPG radiograph scan, as the relationship and proximity of the mandibular impacted third molar roots to the inferior alveolar canal (IAC), this alerts the surgeon to be careful in the approach to different types of surgery in the area. ${ }^{13-15}$ A literature research revealed a lack of studies showing the relation of the impacted mandibular third molar roots to IAC in Kurdish population/ Iraq. Therefore, the aim of this study was to examine the relationship and proximity of the impacted mandibular third molar roots to the IAC in relation to the gender, age, depth of impaction, mandibular ramus, and angulation of impacted tooth in Kurdistan population, Iraq.

\section{Methods}

A retrospective study of a sample size of 366 digital panoramic radiographs of patients with impacted mandibular third molar in the period between 2013 and 2015. The data were gathered from the Diagnostics Department at the College of Dentistry/ Hawler Medical University. The panoramic images were performed using the (Fona XPan DGPlus, Italia). The research project was approved by the Research Ethics Committee at College of Dentistry, Hawler Medical University under the protocol. The inclusion criteria employed in this study were (i) patients with 20-25 years old, (ii) the presence of fully visible unilateral or bilateral impacted mandibular third molars (iii) visible inferior alveolar canals, and the impacted teeth with one radiographical feature regarding the proximity to IAC. Any radiographic record which showed pathology or resorption in apical area of mandibular third molars, radiographical features of the presence of alveolar bone separating the apex of impacted tooth from the canal, craniofacial anomalies (e.g. Down syndrome and cleidocranial dysostosis), any prior extraction of the mandibular third molar, or had any missing mandibular second molars were excluded in this study. Study variables: All assessment was done by two examiners. Prior to the study, a pilot study was carried out where 40 OPGs were examined until complete inter-examiner reliability and reproducibility achieved. Radiographic data were collected from panoramic radiographs and the relative relationship and proximity of the mandibular third molar roots to the IAC can be predicted by several radiographic signs, four signs for the root and four signs for the canal was studied as explained by Gomes et al. (2005) and Beirne and Hujoel $(2012)^{16,17}$ with some modification (Figure 1):

1. Roots of the mandibular third molar in contact with the superior border of the mandibular canal.

2. Darkening of the roots apex: Usually the density of the root is the same throughout its length, but when there is impingement of the canal on the tooth root, there is a loss of density of the root and the root appears darker.

3. Deflected roots: A close, proximal relationship of root to the mandibular canal may be seen as an abrupt deviation of the root as it encounters the inferior alveolar canal.

4. Narrow root: Narrowing of the root where the canal crosses.

5. Superimposition of the canal. This occurs when the superior and inferior cortical bone borders of the mandibular canal are superimposed on the root of the third molar.

6. Interruption of the white line: The white lines are the two radio-opaque lines that constitute the roof and floor of the inferior alveolar canal. The white line is considered to be interrupted when the root lies in the canal, and the white line of the superior 
border of the canal may be absent.

7. Diversion of the inferior alveolar canal: The canal is considered to be diverted if, when it crosses the mandibular third molar, it changes its direction.

8. Narrowing of the inferior alveolar canal: This refers to the constriction of the inferior alveolar canal and can be indicative of a close proximity of the nerve to the tooth. Age and gender were recorded as demographic variables. To consider the third molar as impacted, the third molar should not have a functional occlusion while the root formation is completed ${ }^{16}$. According to the Pell and Gregory classification, the relation of the cementoenamel junction of the third molar with the bone level is categorized as follows: Level A: Not buried in bone; level $\mathrm{B}$ : Partially buried in bone if any part of CEJ was lower than bone level; level C: Completely buried in bone. ${ }^{18}$ According to the Pell and Gregory classification, the position of the distal surface of the third molar crown in relation to the anterior border of the ascending ramus is categorized as follows: Class I: There is sufficient space available between the anterior border of the ascending ramus and the distal aspect of the second molar for the eruption of the third molar. Class II: The space available between the
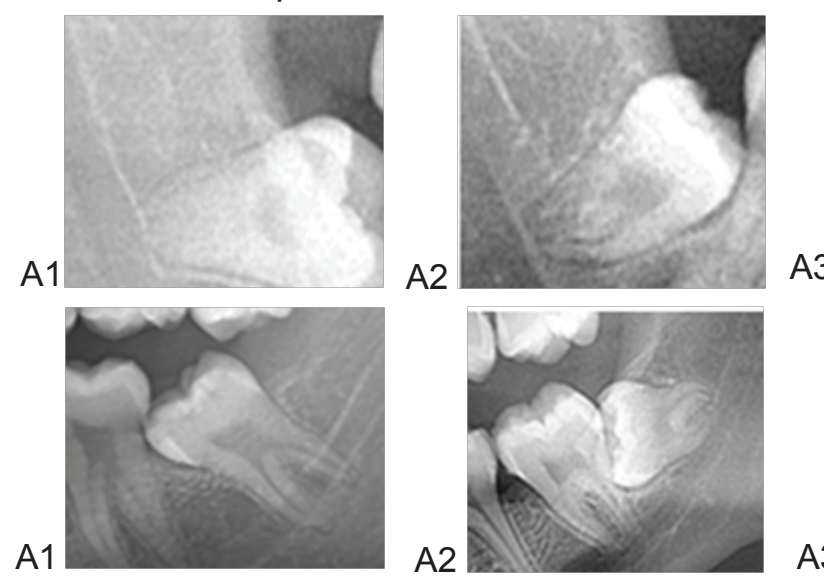
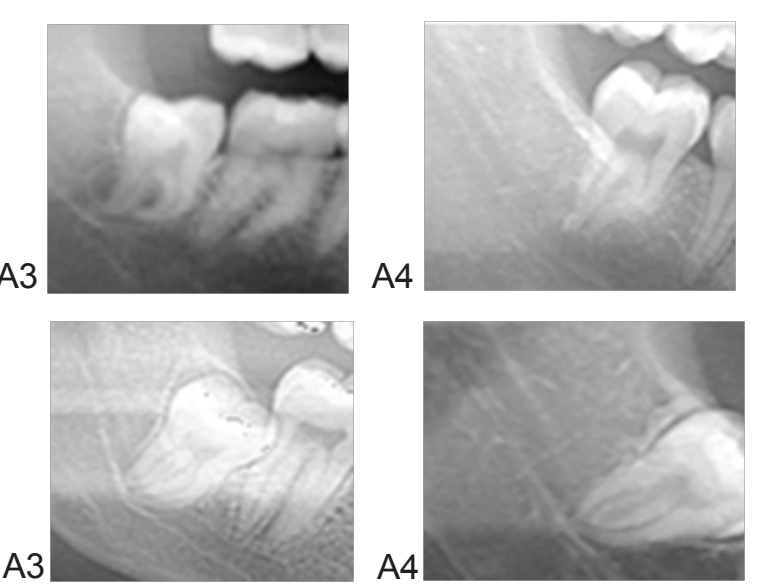

Figure 1: the relative relationship and proximity of the mandibular $3 r d$ molar roots to the inferior alveolar canal. (A1) Contact with the superior border (A2), Darkening of the roots apex, (A3) Deflected roots, (A4) Narrow roots, (B1) Superimposition of the canal, (B2) Interruption of white line, (B3) Deversion of the inferior alveolar canal, (B4) Narrowing of the inferior alveolar canal. 


\section{Results}

The OPGs of patients studied which fulfill the inclusion criteria were 366 . The number of OPGs in males was 132 OPG $(36.07 \%)$ and the number of OPGs in females was $234(63.93 \%)$. Table 1 shows that there is a significant difference in the gender distribution regarding the number of OPGs with the impacted mandibular third molar $(P=0.001)$. The total number of impacted teeth studied was 642 (316 in the right side and 326 in the left side). The number of impacted teeth in males was 279 (43.46\%) and the number of impacted teeth in females was 363 (56.54\%). Table 2 shows that there is a significant difference in the number of impacted teeth present between males and females $(P=0.001)$. The relative relationship and proximity of the mandibular third molar roots to the IAC in relation to gender and age are seen in Table 3. The proportions of females were more than males in all the apex relations especially the narrowing of the roots $(71.43 \%)$. Statistical analysis showed significant relation present between the gender and relationship of the mandibular third molar roots to the IAC $(P=0.001)$. In every age group, the percentages of impacted teeth in which the root touch the superior border of the IAC was seen more frequently than the other types of relations. Statistical analysis showed a significant difference between every age group and the relationship of the mandibular third molar roots to the IAC $(P<0.001)$. The distribution of impacted teeth according to different parameters used in the study is present in Table 4. There was a higher prevalence of teeth with depth $\mathrm{C}$ of impaction $(309,48.13 \%)$, most of the teeth were classified as Class II $(246,38.32 \%)$, vertical angulation showed higher prevalence $(351,54.67 \%)$ and most of the teeth seen just touch the superior border of IAC (34.89\%). The number of aberrant teeth was $13(2.02 \%)$, and only one tooth seen in contact with the superior border of the mandibular canal, and most of them are away (Figure 2), so this type of angulation was excluded from the study.

Table 1: Distribution of patients by gender and age.

\begin{tabular}{lccccc}
\hline \multirow{2}{*}{ Gender } & \multicolumn{5}{c}{ Age, years (No \& \%) } \\
& $\mathbf{2 0 - 2 1}$ & $\mathbf{2 2 - 2 3}$ & $\mathbf{2 4 - 2 5}$ & Total & P value \\
\hline Male & $28(21.21 \%)$ & $62(46.97 \%)$ & $42(31.82 \%)$ & $132(100 \%)$ & \\
Female & $67(28.63 \%)$ & $82(35.04 \%)$ & $85(36.33 \%)$ & $234(100 \%)$ & 0.001 \\
Total & $95(25.95 \%)$ & $144(39.35 \%)$ & $127(34.7 \%)$ & $366(100 \%)$ & \\
\hline
\end{tabular}

Table 2: Distribution of the impacted mandibular third molars by gender and age of the patients.

\begin{tabular}{lccccc}
\hline \multirow{2}{*}{ Gender } & \multicolumn{5}{c}{ Age, years (No \& \%) } \\
\\
\hline Male & $\mathbf{2 0 - 2 1}$ & $\mathbf{2 2 - 2 3}$ & $\mathbf{2 4 - 2 5}$ & Total & P value \\
Female & $115(41.22 \%)$ & $98(35.13 \%)$ & $66(23.65 \%)$ & $279(100 \%)$ & \\
Total & $119(32.78 \%)$ & $143(39.39 \%)$ & $101(72.83 \%)$ & $363(100 \%)$ & 0.001 \\
\hline
\end{tabular}


Table 3: The radiographic signs for the relative relationship of the mandibular third molar roots to the inferior alveolar canal according to the gender and age.

\begin{tabular}{|c|c|c|c|c|c|c|c|c|c|c|c|}
\hline \multirow{2}{*}{$\begin{array}{l}\text { Apex relation to } \\
\text { IAC }\end{array}$} & \multicolumn{4}{|c|}{$\begin{array}{l}\text { Gender } \\
\text { (No \& \%) }\end{array}$} & \multicolumn{7}{|c|}{$\begin{array}{l}\text { Age (years) } \\
\text { (No \& \%) }\end{array}$} \\
\hline & Male & Female & $\begin{array}{c}\begin{array}{c}\text { Total } \\
\text { (No\&\%) }\end{array} \\
\end{array}$ & $\begin{array}{c}P \\
\text { value }\end{array}$ & $(20-21)$ & $\begin{array}{c}P \\
\text { value }\end{array}$ & $(22-23)$ & $\begin{array}{c}P \\
\text { value }\end{array}$ & $(24-25)$ & $\begin{array}{c}P \\
\text { value }\end{array}$ & $\begin{array}{c}\text { Total } \\
\text { (No\&\%) }\end{array}$ \\
\hline $\begin{array}{l}\text { Touch superior } \\
\text { border }\end{array}$ & $\begin{array}{c}110 \\
(49.11 \%)\end{array}$ & $\begin{array}{c}114 \\
(50.89 \%)\end{array}$ & $\begin{array}{c}224 \\
(100 \%)\end{array}$ & 0.001 & $\begin{array}{c}91 \\
(38.88 \%)\end{array}$ & $<0.001$ & $\begin{array}{c}70 \\
(29.0 \%)\end{array}$ & $<0.001$ & $\begin{array}{c}63 \\
(37.72 \%)\end{array}$ & $<0.001$ & $\begin{array}{c}224 \\
(100 \%)\end{array}$ \\
\hline $\begin{array}{l}\text { Darkening of } \\
\text { roots }\end{array}$ & $\begin{array}{c}58 \\
(37.42 \%)\end{array}$ & $\begin{array}{c}97 \\
(62.58 \%)\end{array}$ & $\begin{array}{c}155 \\
(100 \%)\end{array}$ & & $\begin{array}{c}77 \\
(32.91 \%)\end{array}$ & & $\begin{array}{c}46 \\
(19.1 \%)\end{array}$ & & $\begin{array}{c}32 \\
(19.16 \%)\end{array}$ & & $\begin{array}{c}155 \\
(100 \%)\end{array}$ \\
\hline Deflected roots & $\begin{array}{c}12 \\
(41.38 \%)\end{array}$ & $\begin{array}{c}17 \\
(58.62 \%)\end{array}$ & $\begin{array}{c}29 \\
(100 \%)\end{array}$ & & $\begin{array}{c}5 \\
(2.14 \%)\end{array}$ & & $\begin{array}{c}18 \\
(7.5 \%)\end{array}$ & & $\begin{array}{c}6 \\
(3.6 \%)\end{array}$ & & $\begin{array}{c}29 \\
(100 \%)\end{array}$ \\
\hline $\begin{array}{l}\text { Narrowing of } \\
\text { root }\end{array}$ & $\begin{array}{c}6 \\
(28.57 \%)\end{array}$ & $\begin{array}{c}15 \\
(71.43 \%)\end{array}$ & $\begin{array}{c}21 \\
(100 \%)\end{array}$ & & $\begin{array}{c}2 \\
(0.86 \%)\end{array}$ & & $\begin{array}{c}14 \\
(5.8 \%)\end{array}$ & & $\begin{array}{c}5 \\
(2.99 \%)\end{array}$ & & $\begin{array}{c}21 \\
(100 \%)\end{array}$ \\
\hline Superimposition & $\begin{array}{c}19 \\
(38.78 \%)\end{array}$ & $\begin{array}{c}30 \\
(61.22 \%)\end{array}$ & $\begin{array}{c}49 \\
(100 \%)\end{array}$ & & $\begin{array}{c}19 \\
(8.12 \%)\end{array}$ & & $\begin{array}{c}21 \\
(8.7 \%)\end{array}$ & & $\begin{array}{c}9 \\
(5.39 \%)\end{array}$ & & $\begin{array}{c}49 \\
(100 \%)\end{array}$ \\
\hline $\begin{array}{l}\text { Interruption of } \\
\text { white line }\end{array}$ & $\begin{array}{c}46 \\
(47.42 \%)\end{array}$ & $\begin{array}{c}51 \\
(52.58 \%)\end{array}$ & $\begin{array}{c}97 \\
(100 \%)\end{array}$ & & $\begin{array}{c}17 \\
(7.26 \%)\end{array}$ & & $\begin{array}{c}45 \\
(18.7 \%)\end{array}$ & & $\begin{array}{c}35 \\
(20.96 \%)\end{array}$ & & $\begin{array}{c}97 \\
(100 \%)\end{array}$ \\
\hline Diversion of IAC & $\begin{array}{c}9 \\
(45 \%)\end{array}$ & $\begin{array}{c}11 \\
(55 \%)\end{array}$ & $\begin{array}{c}20 \\
(100 \%)\end{array}$ & & $\begin{array}{c}3 \\
(1.29 \%)\end{array}$ & & $\begin{array}{c}11 \\
(4.6 \%)\end{array}$ & & $\begin{array}{c}6 \\
(3.6 \%)\end{array}$ & & $\begin{array}{c}20 \\
(100 \%)\end{array}$ \\
\hline $\begin{array}{l}\text { Narrowing of } \\
\text { inferior alveolar } \\
\text { canal }\end{array}$ & $\begin{array}{c}19 \\
(40.43 \%)\end{array}$ & $\begin{array}{c}28 \\
(59.57 \%)\end{array}$ & $\begin{array}{c}47 \\
(100 \%)\end{array}$ & & $\begin{array}{c}20 \\
(8.54 \%)\end{array}$ & & $\begin{array}{c}16 \\
(6.6 \%)\end{array}$ & & $\begin{array}{c}11 \\
(6.58 \%)\end{array}$ & & $\begin{array}{c}47 \\
(100 \%)\end{array}$ \\
\hline Total & $\begin{array}{c}279 \\
(43.5 \%)\end{array}$ & $\begin{array}{c}363 \\
(56.5 \%)\end{array}$ & $\begin{array}{c}642 \\
(100 \%)\end{array}$ & & $\begin{array}{c}234 \\
(36.45 \%)\end{array}$ & & $\begin{array}{c}241 \\
(37.5 \%)\end{array}$ & & $\begin{array}{c}167 \\
(26.01 \%)\end{array}$ & & $\begin{array}{c}642 \\
(100 \%)\end{array}$ \\
\hline
\end{tabular}

Table 4: Distribution of the impacted mandibular third molars according to all parameters used in the study.

\begin{tabular}{lccc}
\hline $\begin{array}{l}\text { Depth of the impacted } \\
\text { ( No\&\%) }\end{array}$ & $\begin{array}{c}\text { Relation with } \\
\text { ramus } \\
(\text { No\&\%) }\end{array}$ & $\begin{array}{c}\text { Angulation } \\
(\text { No\&\%) }\end{array}$ & $\begin{array}{c}\text { Proximity to IAC } \\
\text { ( No\&\%) }\end{array}$ \\
\hline A & I & Vertical & Touch superior border $(224,34.89 \%)$ \\
$(184,28.66 \%)$ & $(178,27.73 \%)$ & $(351,54.67 \%)$ & $\begin{array}{c}\text { Darkening of roots }(155,24.14 \%) \\
\text { Deflected roots }(29,4.52 \%)\end{array}$ \\
B & II & Mesioangular & Narrowing of root $(21,3.27 \%)$ \\
$(149,23.21 \%)$ & $(246,38.32 \%)$ & $(202,31.46 \%)$ & Superimposition $(49,7.63 \%)$ \\
C & III & Horizontal & Interruption of white line $(97,15.11 \%)$ \\
$(309,48.13 \%)$ & & $(67,10.44 \%)$ & Diversion of IAC $(20,3.12 \%)$ \\
& $(218,33.95 \%)$ & $\begin{array}{c}\text { Distoangular } \\
(22,3.43 \%)\end{array}$ & Narrowing of IAC $(47,7.32 \%)$ \\
$(642,100 \%)$ & $(642,100 \%)$ & $(642,100 \%)$ & $(642,100 \%)$ \\
\hline
\end{tabular}
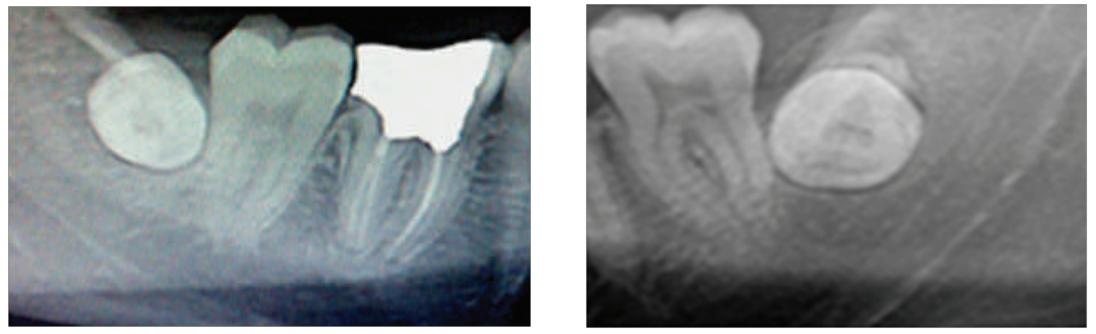

Figure 2: Aberrant teeth are seen away from the inferior alveolar canal ( $A$ and $B$ ). 
The relative relationship and proximity of the mandibular third molar roots to the IAC in relation with the depth of impaction and relation with ramus are seen in Table 5 . The result showed that most of the impacted teeth which touch the superior border of IAC appear at depth A (43.30\%), while all other relations were seen mostly associated with type $\mathrm{C}$ depth of impaction. Statistical analysis showed a significant relation of the proximity of the mandibular third molar roots to the IAC with the depth of impaction $(P<0.001)$. Most of the impacted teeth which touch the superior border of IAC or showed darkening of roots, interruption of the white line, and narrowing of IAC appear mostly in class II relation with the ramus $(39.29 \%, 47.75 \%$, $37.11 \%$ and $40.43 \%$, respectively). Impacted teeth with narrow roots or cause diversion of IAC appear mostly in class III relation with the ramus (47.62, and $40 \%$ respectively). But superimposed teeth appear mostly in class I or class III relation $(40.82 \%)$. Statistical analysis showed a significant relation of the proximity of the mandibular third molar roots to the IAC with the relation of the impacted tooth with the ramus $(P=0.004)$. The relative relationship and proximity of the mandibular third molar roots to the IAC in relation with the angulation of impacted

Table 5: The radiographic signs for the relative relationship of the mandibular third molar roots to the inferior alveolar canal (No.\&\%) according to the depth of impaction and relation with the ramus.

\begin{tabular}{|c|c|c|c|c|c|c|c|c|c|c|}
\hline \multirow{2}{*}{$\begin{array}{l}\text { Apex relation } \\
\text { to IAC }\end{array}$} & \multirow[b]{2}{*}{ A } & \multicolumn{2}{|c|}{$\begin{array}{l}\text { Depth of impaction } \\
\text { (No \& \%) }\end{array}$} & \multirow[b]{2}{*}{$\begin{array}{l}\text { Total } \\
\text { (No\&\%) }\end{array}$} & \multicolumn{4}{|c|}{$\begin{array}{l}\text { Relation with ramus } \\
\text { (No \& \%) }\end{array}$} & \multirow{2}{*}{$\begin{array}{c}\text { Total } \\
\text { (No \& \%) }\end{array}$} & \multirow{2}{*}{$P$ value } \\
\hline & & B & C & & & Class I & Class II & Class III & & \\
\hline $\begin{array}{l}\text { Touch superior } \\
\text { border }\end{array}$ & $\begin{array}{c}97 \\
(43.30 \%)\end{array}$ & $\begin{array}{c}62 \\
(27.67 \%)\end{array}$ & $\begin{array}{c}65 \\
(29.02 \%)\end{array}$ & $\begin{array}{c}224 \\
(100 \%)\end{array}$ & $<0.001$ & $\begin{array}{c}68 \\
(30.35 \%)\end{array}$ & $\begin{array}{c}88 \\
(39.29 \%)\end{array}$ & $\begin{array}{c}68 \\
(30.36 \%)\end{array}$ & $\begin{array}{c}224 \\
(100 \%)\end{array}$ & 0.004 \\
\hline $\begin{array}{l}\text { Darkening of } \\
\text { roots }\end{array}$ & $\begin{array}{c}41 \\
(26.45 \%)\end{array}$ & $\begin{array}{c}29 \\
(18.71 \%)\end{array}$ & $\begin{array}{c}85 \\
(54.84 \%)\end{array}$ & $\begin{array}{c}155 \\
(100 \%)\end{array}$ & & $\begin{array}{c}22 \\
(14.19 \%)\end{array}$ & $\begin{array}{c}74 \\
(47.75 \%)\end{array}$ & $\begin{array}{c}59 \\
(38.06 \%)\end{array}$ & $\begin{array}{c}155 \\
(100 \%)\end{array}$ & \\
\hline Deflected roots & $\begin{array}{c}6 \\
(20.69 \%)\end{array}$ & $\begin{array}{c}7 \\
(24.14 \%)\end{array}$ & $\begin{array}{c}16 \\
(55.17 \%)\end{array}$ & $\begin{array}{c}29 \\
(100 \%)\end{array}$ & & $\begin{array}{c}14 \\
(48.27 \%)\end{array}$ & $\begin{array}{c}8 \\
(27.59 \%)\end{array}$ & $\begin{array}{c}7 \\
(24.14 \%)\end{array}$ & $\begin{array}{c}29 \\
(100 \%)\end{array}$ & \\
\hline $\begin{array}{l}\text { Narrowing of } \\
\text { root }\end{array}$ & $\begin{array}{c}5 \\
(23.81 \%)\end{array}$ & $\begin{array}{c}2 \\
(9.52 \%)\end{array}$ & $\begin{array}{c}14 \\
(66.66 \%)\end{array}$ & $\begin{array}{c}21 \\
(100 \%)\end{array}$ & & $\begin{array}{c}4 \\
(19.05 \%)\end{array}$ & $\begin{array}{c}7 \\
(33.33 \%)\end{array}$ & $\begin{array}{c}10 \\
(47.62 \%)\end{array}$ & $\begin{array}{c}21 \\
(100 \%)\end{array}$ & \\
\hline Superimposition & $\begin{array}{c}13 \\
(26.53 \%)\end{array}$ & $\begin{array}{c}11 \\
(22.49 \%)\end{array}$ & $\begin{array}{c}25 \\
(51.02 \%)\end{array}$ & $\begin{array}{c}49 \\
(100 \%)\end{array}$ & & $\begin{array}{c}20 \\
(40.82 \%)\end{array}$ & $\begin{array}{c}9 \\
(18.36 \%)\end{array}$ & $\begin{array}{c}20 \\
(40.82 \%)\end{array}$ & $\begin{array}{c}49 \\
(100 \%)\end{array}$ & \\
\hline $\begin{array}{l}\text { Interruption of } \\
\text { white line }\end{array}$ & $\begin{array}{c}15 \\
(15.46 \%)\end{array}$ & $\begin{array}{c}17 \\
(17.53 \%)\end{array}$ & $\begin{array}{c}65 \\
(67.01 \%)\end{array}$ & $\begin{array}{c}97 \\
(100 \%)\end{array}$ & & $\begin{array}{c}33 \\
(34.02 \%)\end{array}$ & $\begin{array}{c}36 \\
(37.11 \%)\end{array}$ & $\begin{array}{c}28 \\
(28.87 \%)\end{array}$ & $\begin{array}{c}97 \\
(100 \%)\end{array}$ & \\
\hline Diversion of IAC & $\begin{array}{c}5 \\
(25 \%)\end{array}$ & $\begin{array}{c}7 \\
(35 \%)\end{array}$ & $\begin{array}{c}8 \\
(40 \%)\end{array}$ & $\begin{array}{c}20 \\
(100 \%)\end{array}$ & & $\begin{array}{c}7 \\
(35.55 \%)\end{array}$ & $\begin{array}{c}5 \\
(25 \%)\end{array}$ & $\begin{array}{c}8 \\
(40 \%)\end{array}$ & $\begin{array}{c}20 \\
(100 \%)\end{array}$ & \\
\hline $\begin{array}{l}\text { Narrowing of } \\
\text { IAC }\end{array}$ & $\begin{array}{c}2 \\
(4.26 \%)\end{array}$ & $\begin{array}{c}14 \\
(29.79 \%)\end{array}$ & $\begin{array}{c}31 \\
(65.96 \%)\end{array}$ & $\begin{array}{c}47 \\
(100 \%)\end{array}$ & & $\begin{array}{c}10 \\
(21.27 \%)\end{array}$ & $\begin{array}{c}19 \\
(40.43 \%)\end{array}$ & $\begin{array}{c}18 \\
(38.30 \%)\end{array}$ & $\begin{array}{c}47 \\
(100 \%)\end{array}$ & \\
\hline Total & $\begin{array}{c}184 \\
(28.66 \%)\end{array}$ & $\begin{array}{c}149 \\
(23.21 \%)\end{array}$ & $\begin{array}{c}309 \\
(48.13 \%)\end{array}$ & $\begin{array}{c}642 \\
(100 \%)\end{array}$ & & $\begin{array}{c}178 \\
(27.73 \%)\end{array}$ & $\begin{array}{c}246 \\
(38.32 \%)\end{array}$ & $\begin{array}{c}218 \\
(33.96 \%)\end{array}$ & $\begin{array}{c}642 \\
(100 \%)\end{array}$ & \\
\hline
\end{tabular}


tooth are seen in Table 6 . The result showed that the highest percentages of impacted teeth with vertical, mesioangular, and horizontal impaction were seen just touch the superior border of IAC $(30.77 \%, \quad 38.61 \%$, and $44.77 \%$ respectively), followed by the darkening of roots $(25.07 \%, 24.26 \%$, and $23.89 \%$ respectively). But the highest percentages of impacted teeth with distoangular impaction were seen just touch the superior border of IAC (36.37\%), followed by interruption of the white line and narrowing of IAC (13.63\%). Statistical analysis showed a significant relation of the proximity of the mandibular third molar roots to the IAC with the angulation of impaction $(P<0.001)$.

\section{Discussion}

The OPGs of patients studied were 366, and the age range of patients included in the study was $20-25$ years. Hazza'a et al. ${ }^{21}$ found that the greater number of impacted mandibular third molar was seen within the age group 20-25 years. Costa et al. ${ }^{22}$ found that the greater number of impacted mandibular third molar was seen within the age group 21-25 years. For this reason, the age of the patients selected was between 20-25 years. The result showed that the incidence of mandibular third molar impaction was significantly higher in females in comparison to males. Other studies also reported a gender predilection for females. ${ }^{18,23-25}$ The higher incidence in women could be attributed to the fact that the physical growth in women usually stops earlier than men leading to a smaller jaw size. ${ }^{23}$ Moreover, the initiation of third molar eruption in women normally happens after the growth of the jaw is completed. In men, however, the jaw growth continues during the third molar eruption and thus provides more space for the tooth. ${ }^{23}$ In Deshpande et al. ${ }^{26}$ study, there was 42 $(65.6 \%)$ males, and $22(34.4 \%)$ females and the male to female ratio was 1.9:1. In the study sample of the current research, the most common impaction level was Class C (48.13\%). In contrast, some studies found that the most common impaction level was Class $\mathrm{B}^{22,23,27,28}$ while other studies reported Class $A$ as the predominant impaction level. ${ }^{18,29,30}$ This can be explained by the difference in classification methods according to the position of the cementoenamel junction in

Table 6: The radiographic signs for the relative relationship of the mandibular third molar roots to the inferior alveolar canal according to the angulation of impacted tooth.

\begin{tabular}{|c|c|c|c|c|c|}
\hline \multirow{2}{*}{ Apex relation to IAC } & \multicolumn{4}{|c|}{$\begin{array}{l}\text { Angulation of impacted tooth } \\
\text { (No \& \%) }\end{array}$} & \multirow{2}{*}{$P$ value } \\
\hline & Vertical & Mesioangular & Horizontal & Distoangular & \\
\hline Touch superior border & $108(30.77 \%)$ & $78(38.61 \%)$ & $30(44.77 \%)$ & $8(36.37 \%)$ & $<0.001$ \\
\hline Darkening of roots & $88(25.07 \%)$ & $49(24.26 \%)$ & $16(23.89 \%)$ & $2(9.09 \%)$ & \\
\hline Deflected roots & $19(5.41 \%)$ & $7(3.47 \%)$ & $1(1.49 \%)$ & $2(9.09 \%)$ & \\
\hline Narrowing of root & $14(3.99 \%)$ & $5(2.48 \%)$ & $1(1.49 \%)$ & $1(4.55 \%)$ & \\
\hline Superimposition & $25(7.13 \%)$ & $19(9.41 \%)$ & $4(5.97 \%)$ & $1(4.55 \%)$ & \\
\hline Interruption of white line & $54(15.38 \%)$ & $28(13.85 \%)$ & $12(17.92 \%)$ & $3(13.63 \%)$ & \\
\hline Diversion of IAC & $12(3.42 \%)$ & $5(2.48 \%)$ & $1(1.49 \%)$ & $2(9.09 \%)$ & \\
\hline Narrowing of IAC & $31(8.83 \%)$ & $11(5.44 \%)$ & $2(2.98 \%)$ & $3(13.63 \%)$ & \\
\hline Total & $351(100 \%)$ & $202(100 \%)$ & $67(100 \%)$ & $22(100 \%)$ & \\
\hline
\end{tabular}


relation to the alveolar bone level or according to the relationship of occlusal surfaces of the third molar and the adjacent second molar. In the present study, half of the crown was covered with the anterior border of the mandibular ramus (Class II) in most cases studied (38.32\%). This was in compliance with the findings of other studies. $^{18,27-30}$ But these results disagree with that of Costa et al. $(2013)^{22}$; they found that most of the teeth were classified as Class $1(50 \%)$. In the present study, the most common angulation type of impacted mandibular third molar was vertical $(54.67 \%)$. Hazza'a et al. $(2007)^{21}$ found that $66.7 \%$ of the cases of impacted mandibular third molars in Jordanian population were of vertical position. Quek et al. $(2003)^{23}$ in Singaporean, Hassan $(2010)^{31}$ in Saudi, Hashemipour et al. $(2013)^{18}$ in Iran, and Byahatti $(2015)^{32}$ in India found that most of the impaction studied were mesioangular. It should be noted that changes in human lifestyle have resulted in smaller jaws sizes; hence, the space available for the third molars to erupt has decreased. ${ }^{19}$ Furthermore, racial differences can affect the maturation and eruption timing and also the size of the jaw; this would also explain the different rates of incidence reported for different countries. ${ }^{18,27,32}$ In the present study, touching the superior border of the IAC represents the highest percentage than the other types of proximity $(34.89 \%)$, while panoramic signs of the deviation of the canal and narrowing of the roots were the least frequent. Hazza'a et al. ${ }^{21}$ found that superimposition constitutes the highest percentage $(45.5 \%)$ than the other types of proximity. Alabed Mela et al. ${ }^{33}$ found that interruption of the white line of the canal was the most frequent panoramic radiographic sign $(47.0 \%)$. Monaco et al. ${ }^{34}$ and Tantanapornkul et al. ${ }^{35}$ found that panoramic signs of the darkening of the roots and the interruption of the radiopaque border of the canal were the most frequent, while panoramic signs of the deviation of the canal and narrowing of the canal were the least frequent. Shankar et al. ${ }^{36}$ study seven radiographical signs and found that out of the 114 cases $44(38.6 \%)$ cases presented with interruption of the white line, and 29 cases (25.4\%) showed darkening of the root. The differences may be due to the methods used. Statistical analysis showed a significant relation of the proximity of the mandibular third molar roots to the IAC with the depth of impaction $(P<0.001)$, relation with the ramus $(P=0.004)$, and angulation of impaction $(P<0.001))$. No other studies present for comparison. Some authors prefer CBCT for more accurate results about the relation of the apex of impacted mandibular third molar to the mandibular canal. But Fatima and Ahmed ${ }^{37}$ found that panoramic radiographs are as accurate as CBCT is assessing the relation of the mandibular third molar to the mandibular canal. Nakagawa et al. ${ }^{38}$ and Ardakani et al. ${ }^{39}$ studied the reliability of panoramic radiography before surgery in some patients and concluded that panoramic radiography is capable of predicting the relationship between the third molar and the mandibular canal.

\section{Conclusion}

Significant relation of the proximity of the mandibular third molar roots to the inferior alveolar canal with gender, age, depth of impaction, ramus, and angulation of impaction was seen. This result can be used by the surgeon to prevent the unwanted complications of impacted lower third molar teeth surgery.

\section{Conflicts of interest}

The authors report no conflicts of interest.

\section{References}

1. Pogrel MA, Dorfman D, Fallah H. The anatomic structure of the inferior alveolar neurovascular bundle in the third molar region. J Oral Maxillofac Surg 2009; 67(11):2452-4.

2. Lubbers HT, Matthews F, Damerau G, Kruse AL, Obwegeser JA, Gratz KW, et al. Anatomy of impacted lower third molars evaluated by computerized tomography: is there an indication for 3 dimensional imaging? Oral Surg Oral 
Med Oral Pathol Oral Radiol Endod 2011; 111(5):547-50.

3. Anll A, Peker T, Turgut HB, Gülekon IN, Liman F. Variations in the anatomy of the inferior alveolar nerve. $\mathrm{Br} \mathrm{J}$ Oral Maxillofac Surg 2003; 41(4):236-9.

4. Srinivas M, Susarla TBD. How well do clinicians estimate third molar extraction difficulty? J Oral Maxillofac Surg 2005; 63:191-9.

5. Nieves AD, Leonardo BMD, Cosme GMD. Influence of lower third molar position on the incidence of preoperative complications. Oral Surg Oral Med Oral Pathol Oral Radiol Endod 2006; 102:725-32.

6. Jerjes $W$, El-Maaytah $M$, Swinson B, Upile $T$, Thompson G, Gittelmon S, et al. Inferior alveolar nerve injury and surgical difficulty prediction in third molar surgery: the role of dental panoramic tomography. J Clin Dent 2006; 17(5):122-30.

7. Monaco G, Montevecchi M, Bonetti GA, Gatto MR, Checchi L. Reliability of panoramic radiography in evaluating the topographic relationship between the mandibular canal and impacted third molars. J Am Dent Assoc 2004; 135(3):312-8.

8. Valmaseda-Castellón E, Berini-Aytés L, Gay-Escoda C. Inferior alveolar nerve damage after lower third molar surgical extraction: a prospective study of 1117 surgical extractions. Oral Surg Oral Med Oral Pathol Oral Radiol Endod 2001; 92:377-83.

9. Queral-Godoy E, Valmaseda-Castellón E, Berini-Aytés L, Gay- Escoda C. Incidence and evolution of inferior alveolar nerve lesions following lower third molar extraction. Oral Surg Oral Med Oral Pathol Oral Radiol Endod 2005; 99:259-64.

10. Renton T. Prevention of iatrogenic inferior alveolar nerve injuries in relation to dental procedures. SADJ 2010; 65(8):342-4.

11. Leung YY, Cheung LK. Risk factors of neurosensory deficits in lower third molar surgery: an literature review of prospective studies. Int $\mathrm{J}$ Oral Maxillofac Surg 2011; 40(1):1-10.

12. Smith FE. The relative risk of neurosensory deficit following removal of mandibular third molar teeth: the influence of radiography and surgical technique. Oral Surg Oral Med Oral Pathol Oral Radiol Endod 2013; 115:18-24.

13. Szalma J, Lempel E, Jeges S, Szabo G, Olasz L. The prognostic value of panoramic radiography of inferior alveolar nerve damage after mandibular third molar removal: retrospective study of 400 cases. Oral Surg Oral Med Oral Pathol Oral Radiol Endod 2010; 109(2):294-302.

14. Bell GW. Use of dental panoramic tomographs to predict the relation between mandibular third molar teeth and the inferior alveolar nerve. Br J Oral Maxillofac Surg 2004; 42(1):21-7.

15. Blaeser BF, August MA, Donoff RB, Kaban LB, Dodson TB. Panoramic radiographic risk factors for inferior alveolar nerve injury after third molar extraction. J Oral Maxillofac Surg 2003;61:41721.

16. Gomes AC, Vasconcelos BC, de Oliveira e Silva ED, da Silva LC. Lingual nerve damage after mandibular third molar surgery: a randomized clinical trial. J Oral Maxillofac Surg 2005; 63(10):1443-6.

17. Beirne OR, Hujoel P. Radiographic tips on predicting inferior alveolar nerve exposure. J Evid Based Dent Pract 2012; 12(3):48-9.

18. Hashemipour MA, Tahmasbi-Arashlow M, Fahimi -Hanzaei F. Incidence of impacted mandibular and maxillary third molars: A radiographic study in a Southeast Iran population. Med Oral Patol Oral Cir Bucal 2013; 18:e140-5.

19. Eshghpour M, Mortazavi $\mathrm{H}$, Mohammadzadeh RN, Nejat A. Effectiveness of green tea mouthwash in postoperative pain control following surgical removal of impacted third molars: Double blind randomized clinical trial. Daru 2013; 21:59.

20. Quek SL, Tay CK, Tay KH, Toh SL, Lim KC. Pattern of third molar impaction in a Singapore Chinese population: $A$ retrospective radiographic survey. Int J Oral Maxillofac Surg 2003; 32:54852.

21. Hazza'a AM, Albashaireh ZS, Bataineh A. The relationship of the inferior dental canal to the roots of impacted mandibular third molars in a Jordanian population. J Contemp Dent Pract 2006; 7:71-8.

22. Costa FWG, Fontenele HL, Bezerra TP, Ribeiro TR, Carneiro BGDS, Soares ECSS. Correlation between radiographic signs of third molar proximity with inferior alveolar nerve and postoperative occurrence of neurosensory disorders. A prospective, double-blind study. Acta Cir Bras 2013; 28(3):1-5.

23. Quek SL, Tay CK, Tay KH, Toh SL, Lim KC. Pattern of third molar impaction in a Singapore Chinese population: A retrospective radiographic survey. Int J Oral Maxillofac Surg 2003; 32:54852.

24. Kim JC, Choi SS, Wang SJ, Kim SG. Minor complications after mandibular third molar surgery: Type, incidence, and possible prevention. Oral Surg Oral Med Oral Pathol Oral Radiol Endod 2006; 102:e4-11.

25. Eshghpour M, Nejat AH. Dry socket following surgical removal of impacted third molar in an Iranian population: Incidence and risk factors. Niger J Clin Pract 2013; 16:496-500.

26. Deshpande P, Guledgud MV, Karthikeya Patil K. Proximity of Impacted Mandibular Third Molars to the Inferior Alveolar Canal and Its Radiographic Predictors: A Panoramic Radiographic Study. J Maxillofac Oral Surg 2013; 12(2):145-51.

27. Blondeau F, Daniel NG. Extraction of impacted mandibular third molars: Postoperative complications and their risk factors. J Can Dent Assoc 2007; 73:325. 
28. Almendros-Marqués N, Alaejos-Algarra E, compared with surgery. Iran J Radiol 2010; Quinteros-Borgarello $M$, Berini-Aytés $L$, Gay-Escoda C. Factors influencing the prophylactic removal of asymptomatic impacted lower third molars. Int J Oral Maxillofac Surg 2008; 37:29-35.

29. Obiechina AE, Arotiba JT, Fasola AO. Third molar impaction: Evaluation of the symptoms and pattern of impaction of mandibular third molar teeth in Nigerians. Odontostomatol Trop 2001; 24:22-5.

30. Monaco G, Montevecchi M, Bonetti GA, Gatto MR, Checchi L. Reliability of panoramic radiography in evaluating the topographic relationship between the mandibular canal and impacted third molars. J Am Dent Assoc 2004; 135:312-8.

31. Hassan AH. Pattern of third molar impaction in a Saudi population. Clin Cosmet Investig Dent 2010; 2:109-13.

32. Byahatti SM. The relationship of the inferior alveolar nerve canal with the roots of impacted mandibular third molars in a group of the South Indian population. Indian J Oral Sci; 2015; 6(3):108-12.

33. Alabed MO, Tawfik MA, Mansour NA. Assessment of the Relationship between the Mandibular Canal and Impacted Third Molars Using Cone Beam Computed Tomography. Mansoura J Dent 2014; 1(3):49-55.

34. Monaco G, Montevecchi M, Bonetti GA. Reliability of panoramic radiography in evaluating the topographic relationship between the mandibular canal and impacted third molars. J Am Dent Assoc 2004; 135:312-8.

35. Tantanapornkul W, Okouchi K, Fujiwara Y, Yamashiro Y, Maruoka Y, Ohbayashi N, et al. A comparative study of cone beam computed tomography and conventional panoramic radiography in assessing the topographic relationship between the mandibular canal and impacted third molars. Oral Surg Oral Med Oral Pathol Oral Radiol Endod 2007; 103:253-9.

36. Shankar P, Manodh P, Muruganand VG, Murugan A. Assessment of relationship of mandibular third molar root to inferior alveolar nerve nanal using photostimulable phosphor plate. Int J Dent Health Sci 2015; 2(6):1506-18.

37. Fatima MJ, Ahmed MJ. Assessment of the relation of the mandibular third molar to the mandibular canal :A mete analysis comparing panoramic radiograph to cone beam CT. AJST 2015; 6(4):1319-22.

38. Nakagawa $\mathrm{Y}$, Ishii $\mathrm{H}$, Nomura $\mathrm{Y}$, Watanabe NY, Hoshiba D, Kobayashi K, et al. Third molar position: reliability of panoramic radiography. J Oral Maxillofac Surg 2007; 65(7):1303-8.

39. Ardakani E, Booshehri Z, Azam N, Ardakani F. Diagnostic accuracy of panoramicradiography in determining the position of impacted third molars in relation to the inferior dental canal 